\title{
Recurrent thrombocytopenia and Lyme disease
}

\author{
Egidia Miftode ${ }^{1,2^{*}}$, Dănuț Teodor ${ }^{1,2}$, Roxana Lungu ${ }^{1,2}$, Cristina Petrovici ${ }^{1,2}$ \\ From The 9th Edition of the Scientific Days of the National Institute for Infectious Diseases Prof Dr Matei \\ Bals \\ Bucharest, Romania. 23-25 October 2013
}

\section{Background}

Mild or moderate thrombocytopenia is a common feature in Lyme disease, but the recurrence of such a severe form of thrombocytopenia is very rare, and the improving knowledge of atypical possibility of evolution could help clinicians to establish an early diagnosis and treatment by the inclusion of specific serology in the protocol of evaluation.

\section{Case report}

We present the case of a 24 year-old man admitted to the Hospital of Infectious Diseases for headache, myalgia, arthralgia and a previous unrepeated episode of moderate fever. Physical examination at the admission revealed a poor general status, loss of appetite, difficulties in maintaining orthostatic position due to the hypotonia of the lower limbs muscles, absence of meningeal irritation syndrome. He denied any tick bites in the past. Lumbar puncture, cranio-cerebral computed tomography were normal, as well as different serology for EBV, Mycoplasma, HIV, syphilis. The most prominent hematologic feature was a severe thrombocytopenia $(29,000 / \mathrm{cmm})$.

He received ampicillin and dexamethasone and the level of platelets increased progressively to normal during a period of eight days. He was discharged without any complaints, but he returned after 5 days with the same symptoms, and thrombocytopenia $(37,000 / \mathrm{cmm})$. A serology test for Borrelia was performed and it was positive revealing the diagnosis of Lyme disease. The complete remission of thrombocytopenia under the same association of drugs was very rapid - in 4 days. He was discharged after having been treated for three weeks with antibiotic and two weeks of corticotherapy.

* Correspondence: emiftode@yahoo.co.uk

1"Gr.T.Popa" University of Medicine and Pharmacy, Iaşi, Romania

Full list of author information is available at the end of the article
Authors' details

"'Gr.T.Popa" University of Medicine and Pharmacy, Iaşi, Romania. ${ }^{2}$ Hospital of Infectious Diseases, laşi, Romania.

Published: 16 December 2013

doi:10.1186/1471-2334-13-S1-P81

Cite this article as: Miftode et al:: Recurrent thrombocytopenia and

Lyme disease. BMC Infectious Diseases 2013 13(Suppl 1):P81.
Submit your next manuscript to BioMed Central and take full advantage of:

- Convenient online submission

- Thorough peer review

- No space constraints or color figure charges

- Immediate publication on acceptance

- Inclusion in PubMed, CAS, Scopus and Google Scholar

- Research which is freely available for redistribution
() Biomed Central
○ 2013 Miftode et al; licensee BioMed Central Ltd. This is an Open Access article distributed under the terms of the Creative Commons Attribution License (http://creativecommons.org/licenses/by/2.0), which permits unrestricted use, distribution, and reproduction in any medium, provided the original work is properly cited. 